\title{
Research Management in Virtual Organization between Higher Education and Industry for Developing Lecture's Knowledge
}

\author{
Unang Achlison ${ }^{1}$, Mufadhol Mufadhol ${ }^{* 2}$ \\ ${ }^{1}$ Sekolah Tinggi Ilmu Elektronika dan Komputer Semarang/Departement of Electrical \\ Engineering \\ ${ }^{2}$ Sekolah Tinggi IImu Elektronika dan Semarang/Departement of Computer System \\ unang@stekom.ac.id ${ }^{1}$, masyong29@gmail.com²
}

\begin{abstract}
Lecturers adapt to technology rises because the industries have improved business practices and implemented process changes to become more sustainable. The technological innovations can be generated by research projects that can yield useful innovations in industry. Lecture's research in higher education becomes a fundamental need that must be managed sustainability. The policy and strategy in research between higher education and industry will enhance the quality and sustainability of higher education. The concept of research management in virtual organization adopted from a triangular model that related to higher education, industry, and government. The relationship can serve as a model that can adapt technology in industries and develope lecture's knowledge. The research management in virtual organization used in this research is employing direct observation for problem identification and assigning the Internet service requirement and the availability of hardware and software resources. Developing lecture's knowledge by considering polytechnic's lecture becomes the main objective. The implementation of research management in virtual organization allows (1) industry'publish project themes, (2) lecturers can download the project themes as idea, and (3) lecturers submit proposal documents. The data survey are processed with the correlation, scale reliability, and validity analysis by using SPSS 16.0. Based on data survey result, the all indicators of lectiure's knowledge development have positive values and significant correlations.
\end{abstract}

Keywords: Virtual Organization, Higher Education, Industry, Lecture's Knowledge

\section{Introduction}

\subsection{Background}

In this era, higher education analyzes colaborative projects to identify potential industry innovators, so higher education and industry can rapidly manage their capability by quickly analyzing research inputs across a variety of fields [1]. The technological innovations can be generated by research projects such as higher education motivate the lecturers to engage in research that can yield useful innovations in industry [2]. Economic development comes with pollution, social tension, and so on. A learning model in which economic development should be undertaken in small doses in order for the people to adapt gradually. Upgrading human resources has always been a key factor for economic development [3]. Industries have improved business and lecturers adapt to technology rises in research management are among the most commonly discussed for investigating in the quality of higher education.

The problems exist while academics of higher education effort to keep up with technological developments in industry. A study has investigated the research projects with academia and the testing results showed that profit regressions value more then 0.05 on the contribution to R\&D, engineering design, and idea generation. The technical skills relevant for supporting to innovation in $R$ \& $D$ and engineering design activities, but technical skills were not relevant for supporting to generate ideas or product design [4]. In a similar study it was found that in order for higher education to develop a culture of research, they must allocate significant resources for faculty training and support [5]. Many hypotheses regarding the developing lecturer's research competence appear to be not well grounded.

The Indonesian education department has provided facilities in the form of incentive funds to higher educations who develop science and technology utilized with Industry [6]. This paper conducted a case study the accepted proposal by Indonesian education department in 2015 from the industry and higher educations research partnership in Indonesia. The quantity aspect of

Achlison, U., \& Mufadhol, M. (2018). Research Management in Virtual Organization between Higher Education and Industry for Developing Lecture's Knowledge. Kinetik: Game Technology, Information System, Computer Network, Computing, Electronics, and Control, 4(1). doi:http://dx.doi.org/10.22219/kinetik.v4i1.660

Receive June 13, 2018; Revise July 10, 2018; Accepted September 26, 2018 
researches between higher educations and industries can be seen from the result of the accepted research proposals. the result was released by Indonesian education department and shown in Table 1.

Table 1. Results of Accepted Proposal Selection in 2015

\begin{tabular}{ccc}
\hline Higher education & Quantity & Percent $(\%)$ \\
\hline Polytechnic & 1 & 2,9 \\
Institute & 9 & 25,7 \\
University & 25 & 71,4 \\
\hline
\end{tabular}

Source: Litabmas Ditjen Dikti, letter No.1794/E5.2/PL/2015, 03 August 2015

Further analysis showed that Indonesian education department has provided incentive fund to higher educations for developing science and technology in the research project utilized with Industry, but the accepted research proposals were produced by polytechnic still smaller when they were compared with institutes and universities (see Table 1).

Critical Success Factors (CSFs) relating to policy and strategy will enhance the quality and sustainability of higher education in developing countries. The higher educations strongly promote innovation in its research [7]. From policy perpective, Indonesian Pulp and Paper Association reported that tons of paper are consumed due to extensive application of technology. While in 2010, global paper consumption was actually reduced by 1.1 million. But, Indonesian Pulp and Paper Association also reported that the demand for paper is relatively higher [8,9]. From strategic perspective, the TQM application is an issue of ICT (Information and communications technology) in higher education. The virtual organization and advances in technology have also been affecting higher education [10].

This paper proposes a new approach to develop lecture's knowledge by using the policy and strategy between industry and higher education context. This paper aims to utilize research management in virtual organization in order to develop lecture's knowledge of polytechnic.

\subsection{Literature Review}

A relevant research on this topic has been done by Lipińska entitled knowledge management in a virtual organization [11]. Knowledge, which is the most important intangible asset of virtual organizations, is as a result of an effective management process can be transformed into understood as the ability to use knowledge in practice. Virtual organizations operate within in which the activities related to the transfer of information and knowledge, both within companies and between them and the stakeholders, are of particular importance. The creation, dissemination and application of knowledge using appropriate methods and technological tools should be a priority action for users of virtual organizations wishing to achieve an advantage.

Another study conducted by Drosos [12] discussing the role of information technology and knowledge management in higher education. The adoption of IT in higher education as the main objective is to enhance communication and collaboration among the users. The technology can support the process of knowledge sharing, in which there is direct communication of the customers on topics referring to higher education. The most important outputs of Drosos's study suggest that technologies allow users to express both explicit and tacit knowledge, as well as to place them in a virtual network where they can share ideas. Further research, Drosos's study provided insights that exist in the external relationships of the university.

Knowledge curicullums of universities can be developed by adapting to the science and technology development in the industry, and it was called an imperative strategic [13].

This paper proposes a new approach to develop lecture's knowledge by using research management in virtual organization with industry for supporting any ideas of research project to higher education.

\subsection{Theory}

\subsubsection{Research Management}

Evaluation can be defined as "a systematic and objective process designed to assess the relevance, efficiency, and effectiveness of policies, programmes and projects" [14]. A strong reason for conducting research evaluations as inputs in the research management process was better understanding and learning from past experience for the research process [15]. The right

KINETIK Vol. 4, No. 1, February 2019: 1-12 
specification of industrial innovation in research management is needed by lecturers for developing knowledge more efficiently and effectively.

Research management in virtual organization needs an e-research platform. The eresearch platform gives main benefits such as the cooperation development between research centers in higher education and industry. The research management needs databases and it contains tables that store informations such as industry, lectures and research projects [16].

The research management menu can access the pages related with using the management functions, they were 4 (four) parts namely (1) planning; (2) organizing; (3) actuating; and (4) controlling [17].

\subsubsection{Virtual Organization}

Virtual organizations are often characterized as opposed to traditional organizations as part of three dimensions, i.e. space (uniform - diverse), time (synchronous - asynchronous) and mode of interaction (face to face - online). [11] proposed, under this description, adding the fourth dimension, i.e. individual differences (similarities - differences) to highlight the importance of the method of performing work and characteristics of work teams. The diagram of the dimensions of characteristics of virtual and non-virtual organizations is shown in Figure 1.

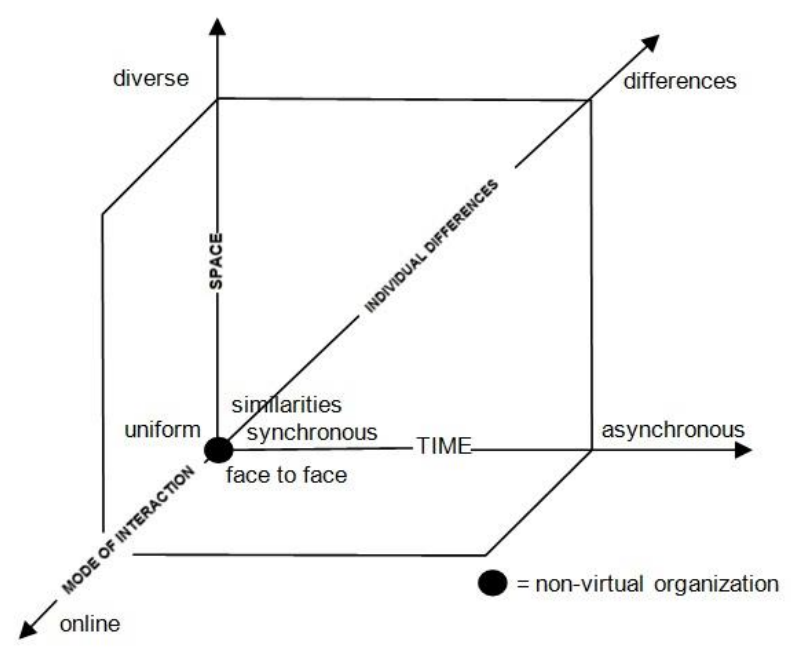

Figure 1. The dimensions of Virtual and Non-Virtual Organizations [11]

[18] attribute the following characteristics to a virtual organization:

1. Adaptability, flexibility, acceptance of change and uncertainty,

2. Increasing the use of resources, know-how and knowledge (intellectual capital),

3. Ability to connect with partners to differentiate the production degree,

4. Reduce the level of bureaucracy, activisation of personnel,

5. Use of information technologies to support management processes (including knowledge management) in an organization.

In summary, a virtual organization is based on information technologies that enable it to use resources and competences dispersed spatially, as well as share information and knowledge within the network created by the company and its stakeholders.

\subsubsection{The Concept of Knowledge}

Knowledge can be defined as the sum total of conserved ideas, facts, experiences and expressed emotions conserved by the society. Humans are the creators and consumers of knowledge to solve problems facing society. Whatever be new knowledge invariably leads to new systems, products, services, values and ultimately the outlook to life and the universe [19].

Society is the producer and consumer of knowledge, while knowledge is the prime mover of society. Knowledge grows as society grows; whereas society changes and develops progressively as new knowledge is generated. It is the society which decides which kind of knowledge it is going to have; in which direction and in how much quantity; and determines the value scales for the different categories of knowledge. Therefore, thrust areas in research to develop new knowledge will depend on the values and priorities of society at a given time. 


\subsubsection{Triple Helix Model}

Triple Helix was described as the university-industrial-government relations [20]. Triple Helix was described as model for studying the knowledge-based economics. Triple Helix model was called Triangle as a program for technological development and endogenous innovation [21]. In globalization era, Triple Helix includes two conclusions, they were: (i) medium-tech industry is more important for synergy than high-tech, and (ii) the service sector tends to uncouple from the geographical location because a knowledge-intensive service is versatile and not geographically constrained.

\section{Research Methods}

The information and knowledge partnership can develop the technology and scientific curriculums of higher education. TriAngular model was one of the information and knowledge partnership. TriAngular model has an impact on the social and economic development, the public sector and the scientific technological solutions [22].

The applied research has implemented in TriAngular model for partnership between higher education and industry to produce the applied research according to government regulations. The applied research implementation is shown in Figure 2.

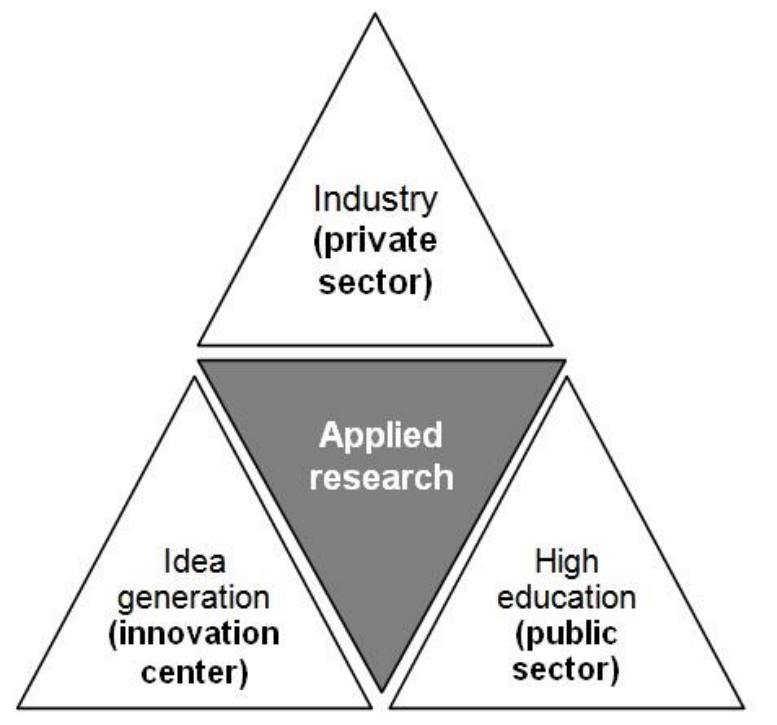

Figure 2. Applied Research Implementation in TriAngular Model [22]

The applied research implementation in TriAngular model for technology transfer can be described as follows:

1. The interaction between the higher education (public sector) and industries (private sector), exchange of experience and strategic decisions by the public sector, also ensuring links between public sector and industries (private sector) environments.

2. Cross-company projects with the support of the government and the potential of research teams and laboratories.

3. Higher education's research projects financed by the government and under a mandatory condition for use in industrial (private sector).

\section{Results and Discussion}

\subsection{Observation for Problem Identification}

Industrial partners in Indonesia who have a product research and development are PT. Hartono Istana Teknologi and PT. PLN. They have an appropriate engineering field for an applied research partnership. The higher education (polytechnic) after obtaining the industrial partners, then use a research cooperation strategy approach to identify the needs of knowledge development in the industry. This stage was implemented as the agendas of focus group discussion with PT. Hartono Istana Teknologi and PT.PLN, the needs of knowledge development in the industry as shown in Table 2.

KINETIK Vol. 4, No. 1, February 2019: 1-12 
Table 2. The Needs of Knowledge Development in the Industry

\begin{tabular}{|c|c|c|c|}
\hline Industry & Vocational skills & Aspect & Information \\
\hline $\begin{array}{l}\text { PT. Hartono } \\
\text { Istana Teknologi }\end{array}$ & $\begin{array}{l}\text { knowledge development includes (1) } \\
\text { a new invention that can be patented, } \\
\text { (2) renewal of the product, and (3) } \\
\text { improvement of existing products }\end{array}$ & $\begin{array}{l}\text { Professional } \\
\text { Competence }\end{array}$ & $\begin{array}{l}\text { there has been no } \\
\text { product innovation } \\
\text { cooperation }\end{array}$ \\
\hline $\begin{array}{l}\text { PT. Perusahaan } \\
\text { Listrik Negara }\end{array}$ & $\begin{array}{l}\text { (1) capable for simulating of data } \\
\text { systems, ( } 2 \text { ) understanding the total } \\
\text { losses of distributed generators, }(3) \\
\text { knowing the impact of distributed } \\
\text { switching process }\end{array}$ & $\begin{array}{l}\text { Pedagogic } \\
\text { Competence }\end{array}$ & $\begin{array}{l}\text { has been } \\
\text { implemented } \\
\text { through an } \\
\text { internship program }\end{array}$ \\
\hline
\end{tabular}

PT. Hartono Istana Teknologi has a field of product innovation that can support the Industrial innovation in research management (see Table 2).

\subsection{Memorandum of Understanding (MoU)}

1. The higher education drafted a proposal of MoU to the industry.

Memorandum of Understanding's content were (1) Objectives, (2) Benefits, (3) Scope, (4) References

2. Government regulations were used as follow:

a. Indonesian Minister of Research, Technology and Higher Education number: 341 / M / $\mathrm{Kp} / \mathrm{V} / 2015$ on "technological incentives program for applied research utilized in the industry".

b. Indonesian Minister of Industrial number 3, year 2014, 4th chapter on the human resources development; 16th article and 4th paragraph: development should be conducted with the research and development of higher educations.

3. Industry send invitation letter to the higher education for signing Memorandum of Understanding.

\subsection{Research Management in Virtual Organization}

The three main components of the knowledge management approach were utilised, with a particular focus on the interrelationship between the three Cs: Content, which was mainly enabled through technical infrastructure; Communication, which allowed for knowledge creation and sharing; and the Consumer, which was active participation and interaction to build commitment for creating online relationships [23]. The implementation between the three Cs:

1. Technical infrastructure.

The web server database was created using PhpMyAdmin and contained several tables for storing data.

2. Knowledge creation and sharing.

The research management applications used a hosting and the domain server's name.

Explanation of the research management as knowledge creation and sharing as follows:

a. Industry registered the project of product development to administrator at the higher education as entry ponit idea.

b. Academics of higher education uploads a research proposal.

c. Industry downloads a research proposal from the approved proposal.

d. Academics in higher education has responsible for doing and reporting the approved proposal as knowledge creation.

e. Industry has responsible for monitoring and receiving the final research results as as knowledge sharing.

f. Academics in higher education have the scientific documents as knowledge outcome.

3. Active participation and interaction.

Explanation of industry innovation in research management model as follows:

a. Academics in higher education send the identities to administrator at the higher education via email. An academic in higher education was a researcher.

b. Person of industry registered the project of product development to administrator at the higher education via email.

c. Research center administrator at the higher education included data: (a). academics, and (b). industrial projects. 
d. Research center administrator at higher education sends username and password to researcher and person of the industry as the reply to each email.

e. Researcher uploads a research proposal by choosing Planning function.

f. Industry downloads a research proposal from the approved proposal by choosing Organizing function.

g. Researcher has responsible for doing and reporting the approved proposal by choosing Actuating function.

h. Industry has responsible for monitoring and receiving the final research results by choosing Controlling function.

i. Academics in higher education have the scientific documents for publication.

The industrial innovation in research management model is shown in Figure 3.

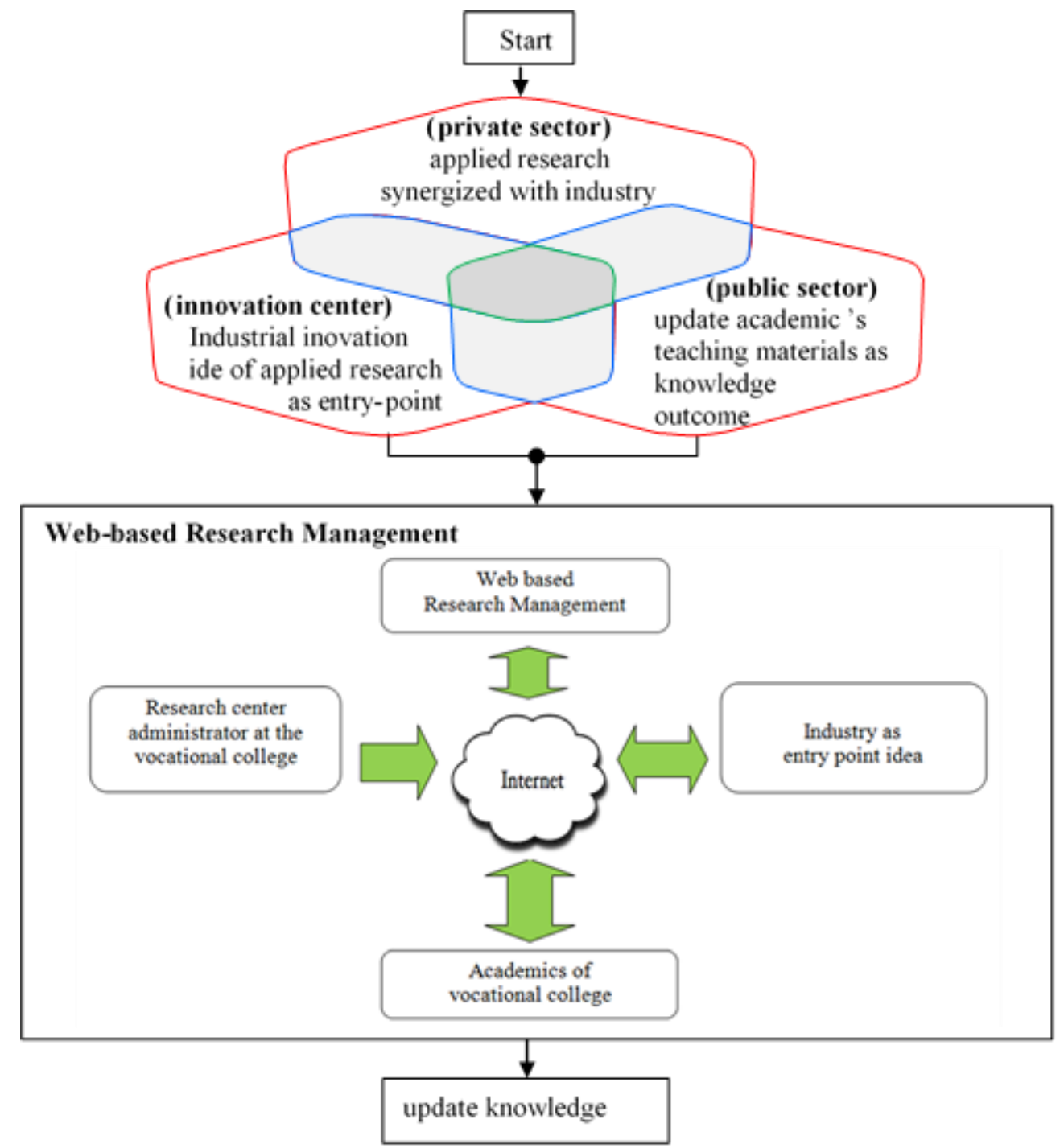

Figure 3. Industrial linnovation in Research Management Model

\subsection{Data Analysis}

The data survey has 10 indicator variables and it was based on spreading questioner to 12 persons in the focus group discussion agenda, they were:

1. Human resource and development staff from PT. Hartono Istana Technology was called expert systems.

2. Research and community service center (innovation center) staff were called expert material and chairman of industrial relations unit at Polytechnic state Semarang as expert judgment. 
3. Lecturers in higher education from polytechnic state Semarang were called users.

The purpose of established polytechnic is polytechnic synergize with industry, so the academic of polytechnic and practitioner of industry have the same characteristic. It is called a homogeneous population [24].

Samples from homogenous population can be taken randomly because the samples are homogeneous. The samples from the homogen population as follows: (a) 4 persons of industry as the expert system, (b) 4 persons of the innovation center as the expert material, and (c) 4 persons of academic or lecturers as users.

Authors spread the questionnaire sheet and it contains 10 questions about the indicator variable. The questions in questionnaire sheet are shown in Table 3.

Table 3. Questions in Questionnaire

\begin{tabular}{cl}
\hline No & \multicolumn{1}{c}{ Indicators of Assessment Model } \\
\hline 1 & do industrial always give some applied research ideas to lecturer? \\
2 & do ideas from industry have an understanding the sustainable industry based? \\
3 & do Lecturer's research accordance to industry have understanding a Planning function? \\
4 & does Industry choose the solutioned proposals have understanding a Organizing \\
& function? \\
5 & do lecturers act for their applied research have understanding a Actuating function? \\
6 & does Industry accepts and supervise the results of lecturer's research have understanding \\
7 & a Controlling function? \\
8 & do lecturers carry out applied research with industry can be used in teaching materials? \\
& $\begin{array}{l}\text { service? } \\
\text { do the applied contents in the web-based can be accessed as the information media }\end{array}$ \\
& $\begin{array}{l}\text { easily? } \\
\text { can lecturers publish the articles after produce documents of potential industry } \\
\text { innovation? }\end{array}$ \\
\hline
\end{tabular}

Based on data survey from spreading questioner to 12 persons, the data survey for 10 indicator variables was obtained by using SPSS 16.0 are shown in Table 4.

Table 4. Data Survey Toward 10 Indicator Variables

\begin{tabular}{lllllllllllll}
\hline & aca-1 & innova-1 & \multicolumn{1}{c}{ ind-1 } & \multicolumn{1}{c}{ ind-2 ind-3 innova-2 } & innova-3 & aca-2 innova-4 ind-4 aca-3 aca-4 \\
\hline Indicator-1 & 3 & 5 & 4 & 3 & 4 & 3 & 3 & 3 & 4 & 4 & 3 & 4 \\
Indicator-2 & 5 & 5 & 4 & 4 & 4 & 4 & 4 & 4 & 4 & 4 & 4 & 4 \\
Indicator-3 & 5 & 4 & 4 & 5 & 4 & 4 & 4 & 4 & 3 & 4 & 4 & 4 \\
Indicator-4 & 4 & 4 & 5 & 5 & 4 & 4 & 4 & 4 & 3 & 4 & 4 & 4 \\
Indicator-5 & 4 & 4 & 5 & 4 & 4 & 4 & 4 & 4 & 4 & 3 & 4 & 4 \\
Indicator-6 & 4 & 4 & 5 & 5 & 4 & 4 & 4 & 4 & 3 & 4 & 4 & 4 \\
Indicator-7 & 5 & 5 & 5 & 5 & 3 & 4 & 4 & 4 & 4 & 3 & 4 & 3 \\
Indicator-8 & 4 & 4 & 5 & 4 & 4 & 4 & 4 & 4 & 4 & 3 & 4 & 4 \\
Indicator-9 & 5 & 5 & 4 & 4 & 4 & 4 & 4 & 4 & 4 & 4 & 4 & 4 \\
Indicator10 & 5 & 4 & 4 & 4 & 4 & 4 & 4 & 4 & 4 & 3 & 4 & 4 \\
\hline
\end{tabular}

Note: aca $=$ academica, innova $=$ innovation center, ind $=$ industry

\section{Correlation Analysis}

Data survey in Table 4 was processed with the correlation and validity analysis. The values of the indicator variables validity were compared with $5 \%$ of critical $R$ person criteria by using SPSS 16.0. The significant value was more than 0,050 on Indicator-1 so this instrument was invalid, while other values are smaller than 0.050 on other Indicators. All Indicators can be concluded that significant and valid for research instruments except the first indicator.

2. Reliability Analysis

Data survey in Table 4 was processed with the reliability and validity analysis. The values of the indicator variables validity are obtained from testing results values with $5 \%$ value of critical R person criteria by using SPSS 16 . According to the guidance for determining size of sample [25], a simple experimental research for successful research is a small sample size between 10 to 20 samples. Interpretation correlation coefficient can be used for $r=0.4 \sim 0.6$, 
it's called "Medium" category interpretation [26]. The values of reliability testing on figure 4 are compared with the value of reliability at $r$ Table according to a number of the expert as $n=12$ and number of questions as $\mathrm{DB}=10$, and number of reliability is obtained at $r$ Table as $r=$ 0,5 .

Significant relationship values were smaller than 0.5 on Indicator- 1 so this instrument does not have the relationship with other instruments, while other values were more than 0.514 on Indicator-2, 3, 4, 5, 6, 7, 8, 9 and 10 so these instruments have a positive and significant relationship with other instruments.

\subsection{Knowledge Development}

\subsubsection{Teaching knowledge}

Evaluation of industry innovation in research management model as knowledge output and especially in the teaching field through questionnaire with the indicator-7 question: "do lecturers carry out applied research with industry can be used in teaching materials?" (see Table 3).

Data survey in Table 4 was processed with the average values analysis for the indicator- 7 question and it is shown in Figure 4.

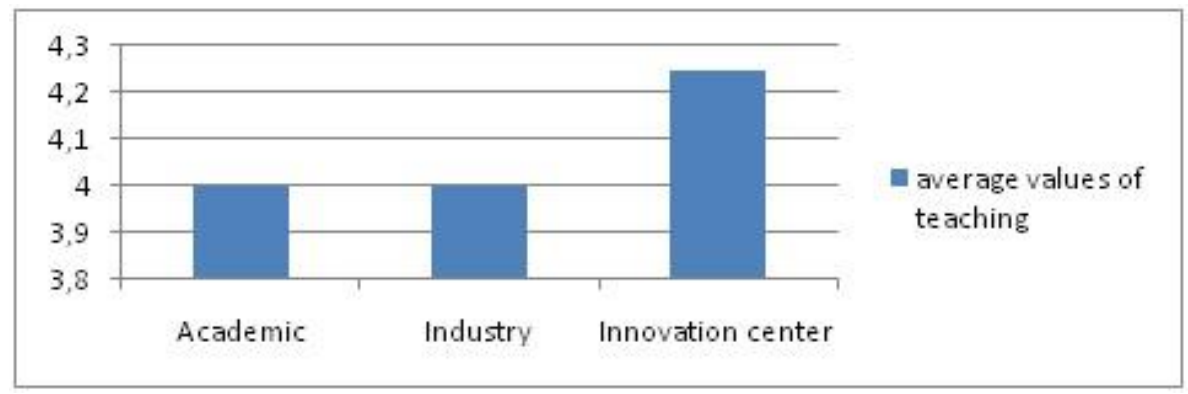

Figure 4. Evaluation of Teaching Knowledge

Based on data survey from spreading questioner to 12 persons, there are good materials from the development of innovation in the industry (Description: $0,5 \leq n \leq 1,5=$ no material, $1,5 \leq n \leq 2,5=$ little material, $2,5 \leq n \leq 3,5=$ less material, $3,5 \leq n \leq 4,5=$ a good material, $4,5 \leq n \leq 5,5=$ many materials). Academics in higher education can work with the Industry for updating the teaching materials.

\subsubsection{Research Knowledge}

Evaluation of industry innovation in research management model as knowledge output and especially in the research field through the questionnaire with the indicator-1 question: "do lecturers always get some applied research ideas from a development of the industrial product?" (see Table 3). Data survey in Table 4 was processed with the average values analysis for the indicator-1 question and it is shown in Figure 5.

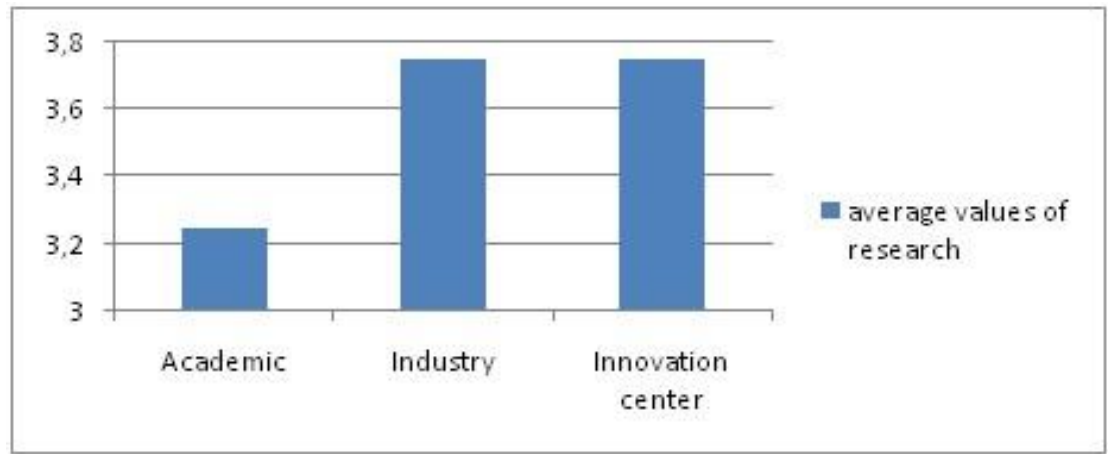

Figure 5. Evaluation of Research Knowledge

Based on data survey from spreading questioner to 12 persons, it is a good idea in the industry, but it was less idea in academics from the development of innovation (Description: $0.5 \leq n \leq 1.5=$ no idea, $1.5 \leq n \leq 2.5$ = little idea, $2.5 \leq n \leq 3.5=$ less idea, $3.5 \leq n \leq 4.5=$ a good idea,

KINETIK Vol. 4, No. 1, February 2019: 1-12 
$4,5 \leq n \leq 5,5=$ many ideas). Academics in higher education need a memorandum of understanding with industry for getting the idea of applied research from product development in the industry.

\subsubsection{Community Service Knowledge}

Evaluation of industry innovation in research management model as knowledge output and especially in the research field through the questionnaire with the indicator-8 question: " does the community service means that Lecturer produces the potential industry innovation?" (see Table 3). Data survey in Table 4 was processed with the average values analysis for the indicator-8 question and it is shown in Figure 6.

Based on data survey from spreading questioner to 12 persons, there is a good innovation from the development of innovation in the industry (Description: $0,5 \leq n \leq 1,5=$ no innovation, $1,5 \leq n \leq 2,5=$ little innovation, $2,5 \leq n \leq 3,5=$ less innovation, $3,5 \leq n \leq 4,5=$ a good innovation, $4,5 \leq n \leq 5,5=$ many innovations). Academics in higher education can generate potential innovation in the industry.

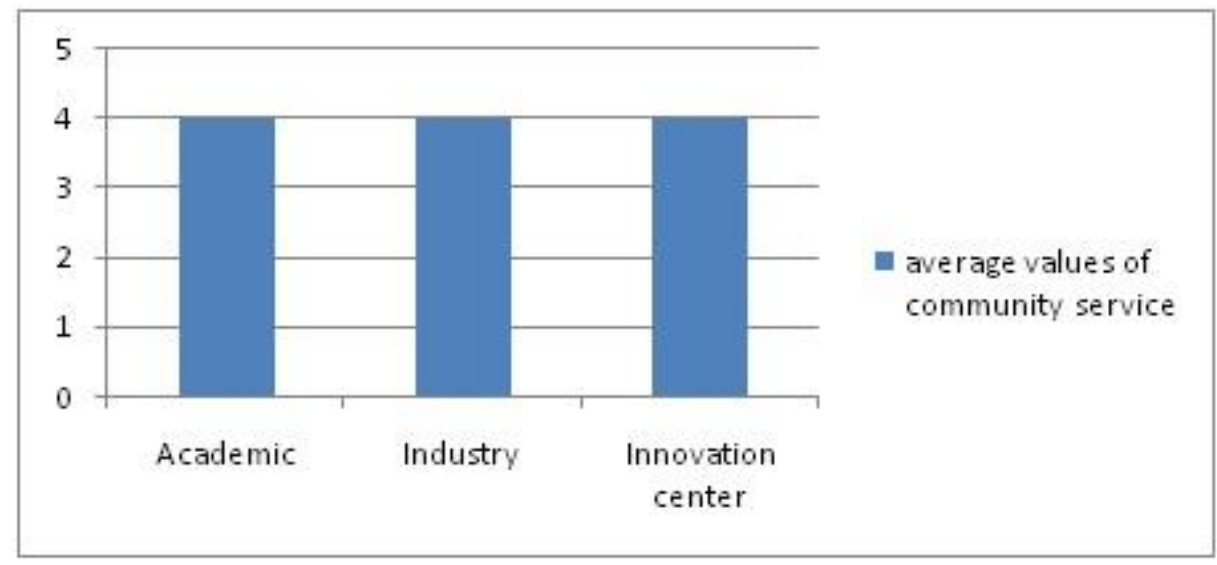

Figure 6. Evaluation Runs the Dharma of Community Service

\subsection{Comparison to an Existing Model}

This paper proposes a new model of developing lecturer's knowledge. The model can be done by using the research management to manage ideas and applied research proposal. In same study, the researcher's competency maped in order to personal effectiveness [27]. The comparison between the model and the map of researcher's competency are shown in Table 5.

Table 5. Comparison to an Existing Model

\begin{tabular}{|c|c|c|}
\hline No. & $\begin{array}{l}\text { Map of Researcher's } \\
\left.\text { Competency }{ }^{*}\right)\end{array}$ & Model Of Developing Lecturer's Knowledge \\
\hline 1 & Select a research topic & 1. Planning, (a) determining title of project or \\
\hline 2 & Conduct literature review & $\begin{array}{l}\text { applied research from product development } \\
\text { in Industry, (b) writing the applied reserch }\end{array}$ \\
\hline 3 & Proposal writing & proposal. \\
\hline & & 2. Update knowledge \\
\hline 4 & $\begin{array}{l}\text { Define appropriate research } \\
\text { methodoloay }\end{array}$ & $\begin{array}{l}\text { 3. Organizing, (a) industry analyzes incoming } \\
\text { Proposal. (b) industry review the solution (c) }\end{array}$ \\
\hline 5 & Manage research funding & industry give fund. \\
\hline 6 & Research implementation & $\begin{array}{l}\text { 4. Actuating, lecturer implement a product } \\
\text { design in industry }\end{array}$ \\
\hline 7 & Research report writing & $\begin{array}{l}\text { 5. Controlling, industry reject or accept final } \\
\text { product }\end{array}$ \\
\hline $\begin{array}{l}8 \\
9\end{array}$ & $\begin{array}{l}\text { Academic publication } \\
\text { Adhering to research ethics }\end{array}$ & 6. Academic Publication \\
\hline
\end{tabular}

Comparison analysis showed that new model of developing lecturer's knowledge has several advantages, they are: 
1. New model devided in 5 steps so simpler.

2. Industry give ideas and update knowledge.

3. Output innovation will be implemented in industry certainly.

Comparison analysis showed that new model of developing lecturer's knowledge has several weaknesses, they are:

1. New model must be supported by the link and match concept in industry.

2. New model needs for identifying potential industry innovators.

\section{Conclusions}

\subsection{Summary}

This study manages the research project of research management in virtual organization as knowledge-outcome between higher education and Industry as a partnership. This study explores the industrial innovation in knowledge-based research management between three departments, they are higher education, industry, and government. This study is validated through a case analysis using: (1) correlation, scale reliability and validity analysis; and (2) teaching, research and community service as knowledge outcome.

Based on data survey from spreading questioner to 12 persons, higher education can work with the Industry for updating the teaching materials. Academics at higher education need a memorandum of understanding with industry for getting the idea of applied research from product development in the industry. Academics in higher education can generate potential innovation in the industry.

Research management in virtual organization has an impact to update academic in higher education for teaching materials.

\subsection{Limitations of the Study}

This model must be supported by the memorandum of understanding in partnership between higher education and Industrial. If higher education does not make a MoU partnership so research management in virtual organization can not effective.

\subsection{Future Scope}

The next study considers the outcome-based implementation of industrial innovation in service field between higher education and Industry.

\section{References}

[1] Hoellrigl, T., and P. Purnell, "Standardization and Flexibility-Field of tension of the Research Management Domain". In 5 th International Symposium on Information Management in a Changing World, IMCW, 2014.

[2] M.A. Schilling, "Manajemen Strategis Inovasi Teknologi". Mc Graw Hill Education, Fourth Edition, Yoyakarta: Pustaka Pelajar, 2015.

[3] Lam, Newman M.K, "Business-Government Relationship in Economic Development," Asian Education and Development Studies, Vol. 5, No. 4, Pp.362-370, 2016.

[4] Müller, K., Rammer, C., and J. Trüby, "The Role of Creative Industries in Industrial Innovation". Innovation, Vol. 11, No.2, Pp. 148-168, 2009.

[5] Hannover, "Building a Culture of Research: Recommended Practices," Academy Administration Practice, Hanover Research, Pp.1-32, May 2014.

[6] RistekDikti, "Panduan Seleksi Insentif Teknologi yang dimanfaatkan di Industri Tahun 2017". Direktorat Jenderal Penguatan Inovasi. Jakarta: Kementerian Riset, Teknologi dan Pendidikan Tinggi, 2016.

[7] Khoja, M., Lemon, M., Fisher, J., and A. Algaddafi, "Integrating the Total Quality Management and Sustainability in the Libyan Higher Education System by Evaluating the Policy and Strategy," International Journal of Learning and Teaching, Vol. 3, No. 2, Np. 160183, June 2017.

[8] AME, "Middle East paper market to consume 29 million tons of paper by 2020", despite digital media growth. [Online] Available at: http://www.ameinfo.com/275456.html., 2011.

[9] Rehiel, S., Jaleel, A., Shittu, K., Mohammed, E., and A. Rheal, "Paperless Office Management: A Feasibility Analysis for Saudi Arabia Government Offices: Case Study in Ministry of Labor," Journal of Management Research, Vol.6, No.3, Pp. 186-198, 2014. 
[10] Mehralizadeh, Y., and M. Safaeemoghaddam, "The Applicability of Quality Management Systems and Models to Higher Education: A New Perspective," The TQM Journal, Vol. 22, No. 2, Pp. 175-187, 2010.

[11] Lipińska, A., "Knowledge Management in a Virtual Organization," Jagiellonian Journal of Management, Vol. 1, No. 1, Pp. 65-76, 2015.

[12] Drosos, D, Skordoulis, M, M. Chalikias, "The Role of Information Technology and Knowledge Management in Higher Education," ICLEL Conferences. Sakarya University Faculty of Education 54300 Sakarya, Turkey, 2016.

[13] Mgijima, Miranda N., "Needs-based Professional Development of Lecturers in Further Education and Training Colleges: A Strategic Imperative," Mediterranean Journal of Social Sciences, Vol. 5, No. 2, January 2014

[14] Marjanovic, Sonja et al, "A Historical Reflection on Research Evaluation Studies, their Recurrent Themes and Challenges". RAND Corporation, Westbrook Centre, Milton Road, Cambridge CB4 1YG, United Kingdom, 2019.

[15] Georghiou, L. and Larédo, P., "Evaluation of Publicly Funded Research: Report on the Berlin Workshop". [Accessed 19 August 2009: http://www.internationalesbuero. de/_media/Report_on_Evaluation_Workshop.pdf]

[16]. Popescu, Brenda and Beju, "Development of a E-Research Platform," Academic Journal Of Manufacturing Engineering, Vol. 9, No. 2, 2011.

[17]. Terry, George, "Dasar-Dasar Manajemen," Jakarta: PT Bumi Aksara. Alma, Cetakan kesebelas, 2010.

[18]. Sroka, H., and Palonka, J., "Problemy kreowania strategii dla organizacji w e-biznesie zamierzenia a realizacje”. In: H. Sroka, \& J. Palonka (eds.), Wpływ systemów e-biznesu na organizacje w aspekcie mikro- i makroekonomicznym (13-36). Katowice: Wydawnictwo Uniwersytetu Ekonomicznego w Katowicach, 2010.

[19]. Satija and Martínez-Ávila, "Mapping of the Universe of Knowledge in Different Classification Schemes, "International Journal of Knowledge Content Development \& Technology, Vol. 7, No. 2, Pp. 85-105, 2017.

[20]. Leydesdorff, L., "The Dynamics of Innovation: from National Systems and "Mode 2" to a Triple Helix of University-Industry-Government," 2000.

[21]. Sábato, J., "El Pensamiento Latinoamericano en la Problemática Ciencia-TechnologíaDesarrollo-Dependencia". Paidós, Buenos Aires, 1975.

[22]. Vutsova, and Ignatova, "The Role of Public-Private Partnership for Effective Technology Trabsfer". Academic Publishing Platform. PRADEC Conference Proceedings, Vol. 2, No. 2, Pp.11-18, 2013.

[23]. Barker, Rachel, "Management of Knowledge Creation and Sharing to Create Virtual Knowledge-Sharing Communities: a Tracking Study, "Journal of Knowledge Management, Vol. 19, No. 2, Pp. 334-350, 2015.

[24]. Sugiyono, "Metode Penelitian Kuantitatif Kualitatif dan R\&D". Bandung: Alfabeta, 2014.

[25]. J.T. Roscoe, "Fundamental Research Statistics for the Behavioral Sciences". New York: Holt, Rinehart and Winston, Inc. Pp. 189-197, 1975.

[26]. Arikunto, S., "Prosedur Penelitian: Suatu Pendekatan Praktik". (Edisi. Revisi). Jakarta: Rineka Cipta, 2010.

[27]. Lasambouwa, C., Sutjiredjekib, E., and N. Nuryatic, "Development of Competency Standard Model for Researchers to Improve Research Capacity of Indonesia's Polytechnic Lecturer, " International Journal of Education and Research, Vol. 3, No. 12, Pp. 53-62, 2015. 